\title{
Experimental Investigation of Isothermal Section of the B-Cr-Fe Phase Diagram at $1353 \mathrm{~K}$
}

\author{
Viera Homolová and Lucia Čiripová \\ Institute of Materials Research, Slovak Academy of Sciences, Watsonova 47, 04001 Košice, Slovakia \\ Correspondence should be addressed to Viera Homolová; vhomolova@saske.sk
}

Received 28 February 2017; Accepted 20 April 2017; Published 11 May 2017

Academic Editor: Pavel Lejcek

Copyright ( 2017 Viera Homolová and Lucia Čiripová. This is an open access article distributed under the Creative Commons Attribution License, which permits unrestricted use, distribution, and reproduction in any medium, provided the original work is properly cited.

\begin{abstract}
The isothermal section of the B-Cr-Fe ternary system was studied experimentally at $1353 \mathrm{~K}$. X-ray diffraction and scanning electron microscopy equipped with EDX analyzer were used for determination of phase equilibria and composition of the coexisting phases in the B-Cr-Fe model alloys after long-term annealing (1500-2205 h). Two iron borides $\mathrm{FeB}$ and $\mathrm{Fe}_{2} \mathrm{~B}$, six chromium borides $\mathrm{Cr}_{2} \mathrm{~B}$, $\mathrm{Cr}_{5} \mathrm{~B}_{3}, \mathrm{CrB}, \mathrm{Cr}_{3} \mathrm{~B}_{4}, \mathrm{CrB}_{2}$, and $\mathrm{CrB}_{4}$ and also iron and chromium solid solutions $(\alpha(\mathrm{Fe}, \mathrm{Cr}), \alpha(\mathrm{Cr}, \mathrm{Fe}), \gamma(\mathrm{Fe}, \mathrm{Cr}))$ and $\beta$-rhombohedral $\mathrm{B}$ were observed in the alloys. High solubilities of the third element in binary borides and no ternary phase were found. Based on the experimental results, isothermal section of the $\mathrm{B}-\mathrm{Cr}-\mathrm{Fe}$ system at $1353 \mathrm{~K}$ was determined.
\end{abstract}

\section{Introduction}

The knowledge about phase equilibria of the B-Cr-Fe system is important in several fields of materials research. The system is subsystem of various complex alloys, for example, modified ferritic steels for energy industry [1-3], steels for production abrasive, and corrosion-resistant components [4]. Information about the system is also important for study of boride coatings on various alloys and metals, including iron $[5,6]$.

Borides of transition metals, including chromium borides, have unique combination of thermal, mechanical, magnetic, and electrophysical properties and are being widely used in atomic power and chemical industry $[7,8]$.

The B-Cr-Fe system has been experimentally studied by only a few authors. Gorbunov and Bodurjan [9] investigated system at $1373 \mathrm{~K}$ after annealing for $320 \mathrm{~h}$ and Chepiga and Kuzma [10] at 973 and $1173 \mathrm{~K}$ after annealing for 400 and $750 \mathrm{~h}$, respectively. In the works $[9,10]$, some questionable phases were found. $\mathrm{CrB}_{6}$ boride, found by Gorbunov and Bodurjan [9] and also by Chepiga and Kuzma [10], is not boride, but it is oxyboride as it was later clarified [11]. Besides the phase, Gorbunov and Bodurjan [9] found $\mathrm{Cr}_{4} \mathrm{~B}$ and $\mathrm{Cr}_{2} \mathrm{~B}_{5}$ phases. The phase that was predicted as $\mathrm{Cr}_{2} \mathrm{~B}_{5}$ was not observed by any other investigators neither in ternary B-CrFe [10] nor in binary B-Cr system [12]. Regarding the $\mathrm{Cr}_{4} \mathrm{~B}$ phase, it was shown that the phase is orthorhombic $\mathrm{Cr}_{2} \mathrm{~B}$ phase [13]. The phase constitution of the system at $1373 \mathrm{~K}$ was investigated also by Gianoglio et al. [14], but, however, only in region up to 50 at $\%$ boron.

The present work is focused on experimental study of phase equilibria of the B-Cr-Fe system at $1353 \mathrm{~K}$ in the entire composition range after long time annealing within 1500 $2205 \mathrm{~h}$ that guarantee to achieve equilibrium state.

\section{Experimental Procedure}

High purity powders of $\mathrm{Fe}(99.98 \%), \mathrm{B}$ (99.9\%), and $\mathrm{Cr}$ (99.99\%) were used as input material for the production of twenty B-Cr-Fe alloys. Powders were mixed, pressed into cylindrical pellets at a pressure of $700 \mathrm{MPa}$, and subsequently melted. The melting was carried out in an argon arc furnace on water cooled copper plate in argon atmosphere of $99.999 \%$ purity. The solidified alloys ( $15 \mathrm{~g}$ ) were remelted several times in order to achieve good homogeneity. The final chemical compositions of the produced alloys were determined by atomic absorption spectroscopy; see Table 1 . The alloys were 
TABLE 1: Chemical compositions of model alloys, conditions of annealing, and phases identified in the alloys after annealing.

\begin{tabular}{|c|c|c|}
\hline Composition [at.\%] & Annealing & Identified phases \\
\hline $17 \mathrm{Fe}-65 \mathrm{~B}-18 \mathrm{Cr}$ & $1353 \mathrm{~K} / 1848 \mathrm{~h}$ & $\mathrm{CrB}_{2}, \mathrm{CrB}_{4}, \mathrm{FeB}$ \\
\hline $33 \mathrm{Fe}-62 \mathrm{~B}-5 \mathrm{Cr}$ & $1353 \mathrm{~K} / 1848 \mathrm{~h}$ & $\mathrm{~B}, \mathrm{FeB}, \mathrm{CrB}_{4}$ \\
\hline $8 \mathrm{Fe}-56 \mathrm{~B}-36 \mathrm{Cr}$ & $1353 \mathrm{~K} / 1848 \mathrm{~h}$ & $\mathrm{Cr}_{3} \mathrm{~B}_{4}, \mathrm{CrB}$ \\
\hline $50 \mathrm{Fe}-40 \mathrm{~B}-10 \mathrm{Cr}$ & $1353 \mathrm{~K} / 1848 \mathrm{~h}$ & $\mathrm{Fe}_{2} \mathrm{~B}, \mathrm{FeB}$ \\
\hline $32 \mathrm{Fe}-40 \mathrm{~B}-28 \mathrm{Cr}$ & $1353 \mathrm{~K} / 1848 \mathrm{~h}$ & $\mathrm{CrB}, \mathrm{FeB}, \mathrm{Cr}_{2} \mathrm{~B}$ \\
\hline $15 \mathrm{Fe}-40 \mathrm{~B}-45 \mathrm{Cr}$ & $1353 \mathrm{~K} / 1848 \mathrm{~h}$ & $\mathrm{CrB}, \mathrm{Cr}_{2} \mathrm{~B}, \mathrm{Cr}_{5} \mathrm{~B}_{3}$ \\
\hline $15 \mathrm{Fe}-25 \mathrm{~B}-60 \mathrm{Cr}$ & $1353 \mathrm{~K} / 1848 \mathrm{~h}$ & $\mathrm{Cr}_{2} \mathrm{~B}, \alpha(\mathrm{Cr}, \mathrm{Fe})$ \\
\hline $8 \mathrm{Fe}-10 \mathrm{~B}-82 \mathrm{Cr}$ & $1353 \mathrm{~K} / 1848 \mathrm{~h}$ & $\mathrm{Cr}_{2} \mathrm{~B}, \alpha(\mathrm{Cr}, \mathrm{Fe})$ \\
\hline $5 \mathrm{Fe}-52 \mathrm{~B}-43 \mathrm{Cr}$ & $1353 \mathrm{~K} / 1848 \mathrm{~h}$ & $\mathrm{CrB}, \mathrm{Cr}_{3} \mathrm{~B}_{4}$ \\
\hline $48 \mathrm{Fe}-10 \mathrm{~B}-42 \mathrm{Cr}$ & $1353 \mathrm{~K} / 1848 \mathrm{~h}$ & $\mathrm{Cr}_{2} \mathrm{~B}, \alpha(\mathrm{Fe}, \mathrm{Cr})$ \\
\hline 70Fe-10B-20Cr & $1353 \mathrm{~K} / 1848 \mathrm{~h}$ & $\mathrm{Cr}_{2} \mathrm{~B}, \alpha(\mathrm{Fe}, \mathrm{Cr})$ \\
\hline $8 \mathrm{Fe}-62 \mathrm{~B}-30 \mathrm{Cr}$ & $1353 \mathrm{~K} / 1848 \mathrm{~h}$ & $\mathrm{CrB}_{2}, \mathrm{Cr}_{3} \mathrm{~B}_{4}$ \\
\hline $10 \mathrm{Fe}-25 \mathrm{~B}-65 \mathrm{Cr}$ & $1353 \mathrm{~K} / 1848 \mathrm{~h}$ & $\mathrm{Cr}_{2} \mathrm{~B}, \alpha(\mathrm{Cr}, \mathrm{Fe})$ \\
\hline $3 \mathrm{Fe}-35 \mathrm{~B}-62 \mathrm{Cr}$ & $1353 \mathrm{~K} / 1848 \mathrm{~h}$ & $\mathrm{Cr}_{2} \mathrm{~B}, \mathrm{Cr}_{5} \mathrm{~B}_{3}$ \\
\hline $10 \mathrm{Fe}-38 \mathrm{~B}-52 \mathrm{Cr}$ & $1353 \mathrm{~K} / 1848 \mathrm{~h}$ & $\mathrm{CrB}, \mathrm{Cr}_{2} \mathrm{~B}, \mathrm{Cr}_{5} \mathrm{~B}_{3}$ \\
\hline $37 \mathrm{Fe}-45 \mathrm{~B}-18 \mathrm{Cr}$ & $1353 \mathrm{~K} / 2205 \mathrm{~h}$ & $\mathrm{Fe}_{2} \mathrm{~B}, \mathrm{FeB}, \mathrm{Cr}_{2} \mathrm{~B}$ \\
\hline $23 \mathrm{Fe}-45 \mathrm{~B}-32 \mathrm{Cr}$ & $1353 \mathrm{~K} / 1500 \mathrm{~h}$ & $\mathrm{Cr}_{2} \mathrm{~B}, \mathrm{CrB}, \mathrm{FeB}$ \\
\hline $29 \mathrm{Fe}-51 \mathrm{~B}-20 \mathrm{Cr}$ & $1353 \mathrm{~K} / 1688 \mathrm{~h}$ & $\mathrm{Cr}_{3} \mathrm{~B}_{4}, \mathrm{CrB}, \mathrm{FeB}$ \\
\hline $20 \mathrm{Fe}-52 \mathrm{~B}-28 \mathrm{Cr}$ & $1353 \mathrm{~K} / 1688 \mathrm{~h}$ & $\mathrm{Cr}_{3} \mathrm{~B}_{4}, \mathrm{CrB}, \mathrm{FeB}$ \\
\hline $45 \mathrm{Fe}-30 \mathrm{~B}-25 \mathrm{Cr}$ & $1353 \mathrm{~K} / 2205 \mathrm{~h}$ & $\mathrm{Cr}_{2} \mathrm{~B}, \mathrm{Fe}_{2} \mathrm{~B}, \gamma(\mathrm{Fe}, \mathrm{Cr})$ \\
\hline
\end{tabular}

then sealed into evacuated silica glass tubes with titanium turnings and annealed at $1353 \mathrm{~K}$ within $1500-2205 \mathrm{~h}$. After the annealing, the samples were quenched into cold water.

The annealed material was studied by X-ray diffraction (Philips X'Pert Pro) and scanning electron microscopy (JEOL JSM-7000F) equipped with “Thermal FEG” and INCA EDX analyzer. The analyzer enables quantitative analysis for elements above and including atomic number 5 (boron). Backscattered electron image mode of scanning electron microscopy was used to study the alloy microstructure.

\section{Results and Discussion}

All phases identified by experimental method in alloys are given in Table 1. Two iron borides $\mathrm{FeB}$ and $\mathrm{Fe}_{2} \mathrm{~B}$, six chromium borides $\mathrm{Cr}_{2} \mathrm{~B}, \mathrm{Cr}_{5} \mathrm{~B}_{3}, \mathrm{CrB}, \mathrm{Cr}_{3} \mathrm{~B}_{4}, \mathrm{CrB}_{2}$, and $\mathrm{CrB}_{4}$, and also iron and chromium solid solutions $(\alpha(\mathrm{Fe}, \mathrm{Cr})$, $\alpha(\mathrm{Cr}, \mathrm{Fe}), \gamma(\mathrm{Fe}, \mathrm{Cr}))$ and $\beta$-rhombohedral $\mathrm{B}$ were found in alloys. The borides in the system form at high temperatures. Most of them form from the liquid during production process of the alloys. Following long-term isothermal annealing leads to achievement of equilibrium chemical compositions of the phases. Crystallographic phase data of observed borides are given in Table 2 . The $\mathrm{CrB}_{4}$ boride was found in $17 \mathrm{Fe}-65 \mathrm{~B}-18 \mathrm{Cr}$ and $33 \mathrm{Fe}-62 \mathrm{~B}-5 \mathrm{Cr}$ alloys. This phase, known from binary $\mathrm{B}-$ $\mathrm{Cr}$ system [12], has not been observed in ternary B-Cr-Fe system till now $[9,10]$. The $\mathrm{Cr}_{2} \mathrm{~B}_{5}$ boride that was found by Gorbunov and Bodurjan at $1373 \mathrm{~K}$ after annealing for $320 \mathrm{~h}$ was not found. No ternary phase was found in the B-Cr$\mathrm{Fe}$ system. It is in accordance with the mentioned literature $[9,10,14]$.
TABLE 2: Crystal structure data of borides.

\begin{tabular}{lccc}
\hline Phase & Pearson symbol & Space group & Reference \\
\hline $\mathrm{FeB}$ & oP8 & Pbmn & {$[15]$} \\
$\mathrm{Fe}_{2} \mathrm{~B}$ & $\mathrm{tI} 12$ & $\mathrm{I} 4 / \mathrm{mcm}$ & {$[15]$} \\
$\mathrm{CrB}_{4}$ & oI10 & $\mathrm{Immm}$ & {$[12]$} \\
$\mathrm{CrB}_{2}$ & $\mathrm{hP3}$ & $\mathrm{P} 6 / \mathrm{mmm}$ & {$[12]$} \\
$\mathrm{Cr}_{3} \mathrm{~B}_{4}$ & oI14 & $\mathrm{Immm}$ & {$[12]$} \\
$\mathrm{CrB}$ & $\mathrm{oC} 8$ & $\mathrm{Cmcm}$ & {$[12]$} \\
$\mathrm{Cr}_{5} \mathrm{~B}_{3}$ & $\mathrm{tI} 32$ & $\mathrm{I} / \mathrm{mcm}$ & {$[12]$} \\
$\mathrm{Cr}_{2} \mathrm{~B}$ & oF40 & Fddd & {$[12]$} \\
\hline
\end{tabular}

TABLE 3: Three-phase fields in experimentally determined B-Cr-Fe phase diagram at $1373 \mathrm{~K}$ according to the literature $[9,14]$.

\begin{tabular}{|c|c|}
\hline [9] & {$[14]$} \\
\hline \multicolumn{2}{|l|}{$\mathrm{FeB} \mathrm{B} \mathrm{CrB} 6$} \\
\hline \multicolumn{2}{|l|}{$\mathrm{FeB} \mathrm{CrB}{ }_{6} \mathrm{Cr}_{2} \mathrm{~B}_{5}$} \\
\hline \multicolumn{2}{|l|}{$\mathrm{FeB} \mathrm{Cr}_{2} \mathrm{~B}_{5} \mathrm{CrB}_{2}$} \\
\hline \multicolumn{2}{|l|}{$\mathrm{FeB} \mathrm{CrB}{ }_{2} \mathrm{Cr}_{3} \mathrm{~B}_{4}$} \\
\hline \multicolumn{2}{|l|}{$\mathrm{FeB} \mathrm{CrB} \mathrm{Cr}{ }_{3} \mathrm{~B}_{4}$} \\
\hline $\mathrm{FeB} \mathrm{Fe}_{2} \mathrm{~B} \mathrm{Cr}{ }_{2} \mathrm{~B}$ & $\mathrm{FeB} \mathrm{Fe}_{2} \mathrm{~B} \mathrm{Cr}{ }_{2} \mathrm{~B}$ \\
\hline $\mathrm{FeB} \mathrm{Cr}{ }_{2} \mathrm{~B} \mathrm{CrB}$ & $\mathrm{FeB} \mathrm{Cr}{ }_{2} \mathrm{~B} \mathrm{CrB}$ \\
\hline $\mathrm{Cr}_{2} \mathrm{~B} \mathrm{Cr}_{5} \mathrm{~B}_{3} \mathrm{CrB}$ & $\mathrm{Cr}_{2} \mathrm{~B} \mathrm{Cr}_{5} \mathrm{~B}_{3} \mathrm{CrB}$ \\
\hline $\mathrm{Fe}_{2} \mathrm{~B} \alpha(\mathrm{Fe}, \mathrm{Cr}) \gamma(\mathrm{Fe}, \mathrm{Cr})$ & $\mathrm{Fe}_{2} \mathrm{~B} \alpha(\mathrm{Fe}, \mathrm{Cr}) \gamma(\mathrm{Fe}, \mathrm{Cr})$ \\
\hline $\mathrm{Fe}_{2} \mathrm{~B} \alpha(\mathrm{Fe}, \mathrm{Cr}) \mathrm{Cr}_{2} \mathrm{~B}$ & $\mathrm{Fe}_{2} \mathrm{~B} \alpha(\mathrm{Fe}, \mathrm{Cr}) \mathrm{Cr}_{2} \mathrm{~B}$ \\
\hline $\mathrm{Cr}_{2} \mathrm{~B} \mathrm{Cr}{ }_{4} \mathrm{~B} \alpha(\mathrm{Cr}, \mathrm{Fe})$ & \\
\hline
\end{tabular}

Figure 1 shows SEM microstructure of the selected alloys. EDX-spectra of the borides in alloys are illustrated on Figure 2. X-ray diffraction patterns of the selected alloys are shown on Figure 3.

Four three-phase equilibria $\mathrm{FeB}+\mathrm{CrB}_{4}+\mathrm{B}$ (Figure $1(\mathrm{~d})$ ), $\mathrm{FeB}+\mathrm{CrB}_{4}+\mathrm{CrB}_{2}, \mathrm{FeB}+\mathrm{CrB}_{2}+\mathrm{Cr}_{3} \mathrm{~B}_{4}$, and $\mathrm{FeB}+\mathrm{Cr}_{3} \mathrm{~B}_{4}+\mathrm{CrB}$ (Figure 3(a)) were found in the part of phase diagram with boron content up 50 at.\% (Figure 4). There are some differences between phase equilibria presented in this paper and equilibria at $1373 \mathrm{~K}$ from work [9], as shown in Table 3 . The differences in this part of the phase diagram are connected with the $\mathrm{CrB}_{6}$ and $\mathrm{Cr}_{2} \mathrm{~B}_{5}$ phases [9]. However, the $\mathrm{CrB}_{6}$ phase, as was mentioned in introduction, is not right determined. The existence of $\mathrm{Cr}_{2} \mathrm{~B}_{5}$ boride was not confirmed by present experimental results.

A part of the isothermal section of the phase diagram with boron range 33-50 at.\% contains three three-phase equilibria $\mathrm{CrB}+\mathrm{Cr}_{5} \mathrm{~B}_{3}+\mathrm{Cr}_{2} \mathrm{~B}$ (Figure 3(c)), $\mathrm{FeB}+\mathrm{Cr}_{2} \mathrm{~B}+\mathrm{Fe}_{2} \mathrm{~B}$, and $\mathrm{FeB}+\mathrm{CrB}+\mathrm{Cr}_{2} \mathrm{~B}$ (Figure 4 ). The same three-phase equilibria were found also at $1373 \mathrm{~K}$ in the works $[9,14]$.

Two three-phase equilibria $\mathrm{Fe}_{2} \mathrm{~B}+\mathrm{Cr}_{2} \mathrm{~B}+\gamma(\mathrm{Fe}, \mathrm{Cr}$ ) (Figure $3(\mathrm{f}))$ and $\mathrm{Cr}_{2} \mathrm{~B}+\gamma(\mathrm{Fe}, \mathrm{Cr})+\alpha(\mathrm{Fe}, \mathrm{Cr})$ are in the iron rich corner of the phase diagram at the temperature $1353 \mathrm{~K}$ (Figure 4). About 9 at.\% of chromium was found in the $\gamma(\mathrm{Fe}, \mathrm{Cr})$-phase in $45 \mathrm{Fe}-30 \mathrm{~B}-25 \mathrm{Cr}$ alloy with phase equilibria 


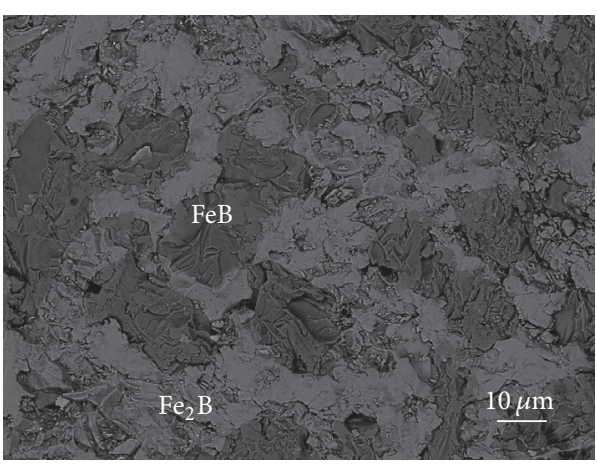

(a)

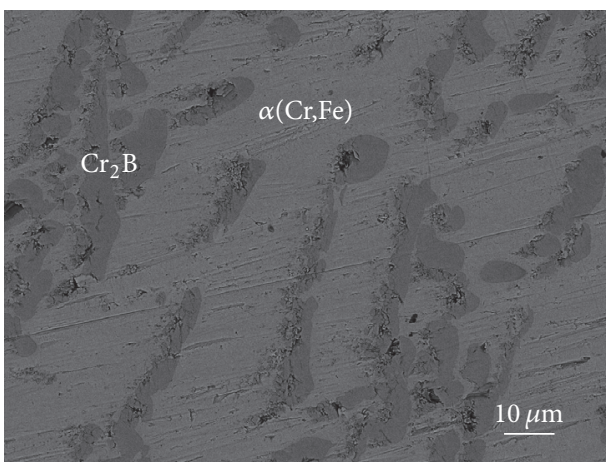

(c)

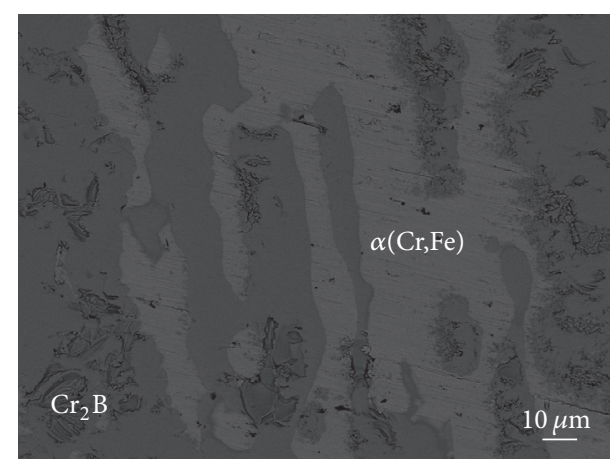

(b)

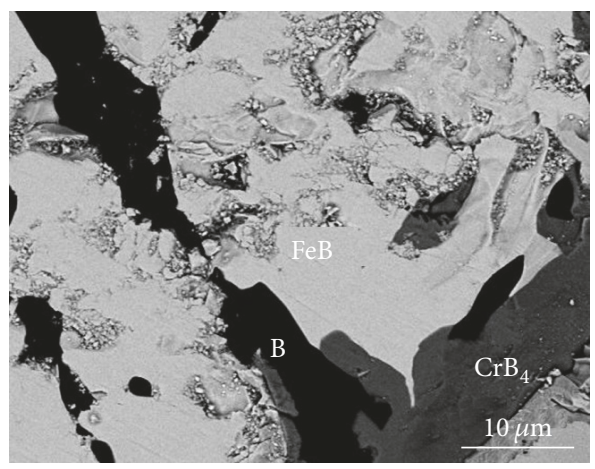

(d)

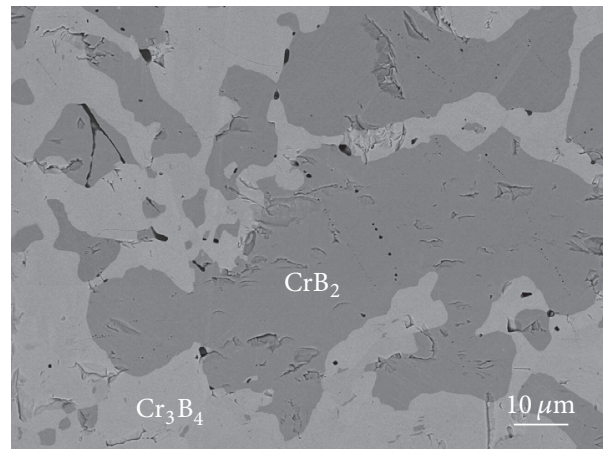

(e)

Figure 1: Microstructure of investigated B-Cr-Fe alloys after annealing at $1353 \mathrm{~K}$ for $1848 \mathrm{~h}$ : 50Fe-40B-10Cr (a); 15Fe-25B-60Cr (b); 8Fe-10B$82 \mathrm{Cr}(\mathrm{c}) ; 33 \mathrm{Fe}-62 \mathrm{~B}-5 \mathrm{Cr}(\mathrm{d}) ; 8 \mathrm{Fe}-62 \mathrm{~B}-30 \mathrm{Cr}(\mathrm{e})$.

$\mathrm{Fe}_{2} \mathrm{~B}+\mathrm{Cr}_{2} \mathrm{~B}+\gamma(\mathrm{Fe}, \mathrm{Cr})$. Both Gorbunov and Bodurjan [9] and Gianoglio et al. [14] found $\mathrm{Fe}_{2} \mathrm{~B}+\mathrm{Cr}_{2} \mathrm{~B}+\alpha(\mathrm{Fe}, \mathrm{Cr})$ and $\mathrm{Fe}_{2} \mathrm{~B}+\gamma(\mathrm{Fe}, \mathrm{Cr})+\alpha(\mathrm{Fe}, \mathrm{Cr})$ equilibria at $1373 \mathrm{~K}$ (Table 3$)$, however, with different amount of chromium in the $\alpha(\mathrm{Fe}, \mathrm{Cr})$ phase in $\mathrm{Fe}_{2} \mathrm{~B}+\mathrm{Cr}_{2} \mathrm{~B}+\alpha(\mathrm{Fe}, \mathrm{Cr})$ equilibrium, about 35 at $\%$ of $\mathrm{Cr}$ according to [9] and 18 at\% according to [14]. The differences between observed phase fields of the part of isothermal section in the present work at $1353 \mathrm{~K}$ and in works $[9,14]$ at $1373 \mathrm{~K}$ indicate that the equilibrium phase fields are changed at temperature from temperature range 1353$1373 \mathrm{~K}$.

All found borides dissolve third element. It is illustrated by EDX-spectra on Figure $2 . \mathrm{Cr}_{2} \mathrm{~B}$ phase has the highest solubility of the third element among all borides in the system.
The boride dissolves up to 39 at.\% of Fe. The solubility is high also in $\mathrm{CrB}, \mathrm{FeB}$, and $\mathrm{Fe}_{2} \mathrm{~B}$ phases. It was found that $\mathrm{Fe}_{2} \mathrm{~B}$ contains up to 15 at. $\%$ of chromium and $\mathrm{FeB}$ dissolves up to 16 at.\% of Cr. The CrB phase dissolves up to 15 at. $\%$ of Fe. Besides them, high solubility of iron is observed also in $\mathrm{Cr}_{3} \mathrm{~B}_{4}$ boride, Figure 2(c), that contains up to 15 at. $\%$ of $\mathrm{Fe}$. Various amounts of dissolved iron were measured also in other chromium borides. In particular, $\mathrm{Cr}_{5} \mathrm{~B}_{3}$ contains up to 6 at.\% of $\mathrm{Fe}, \mathrm{CrB}_{2}$ dissolves up to 2 at. $\%$ of Fe, Figure 2(b), and $\mathrm{CrB}_{4}$ contains up to 7 at. $\%$ of Fe, Figure 2(a).

All the mentioned experimental results, that is, equilibrium phase compositions and composition of phases, were used to determine the isothermal section of $\mathrm{B}-\mathrm{Cr}-\mathrm{Fe}$ phase diagram at $1353 \mathrm{~K}$ that is shown in Figure 4. 


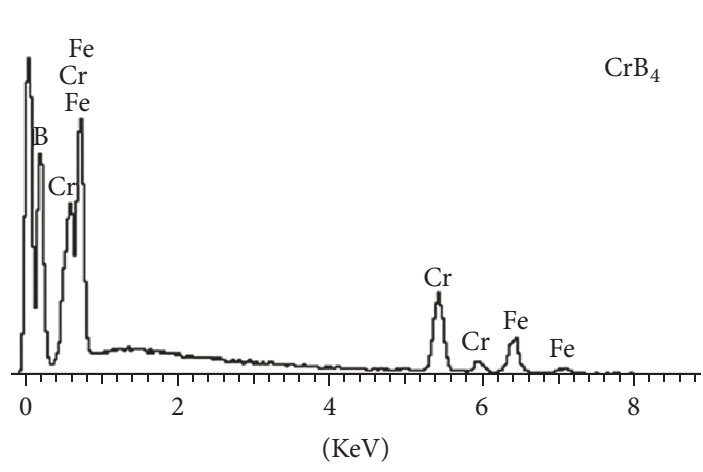

(a)

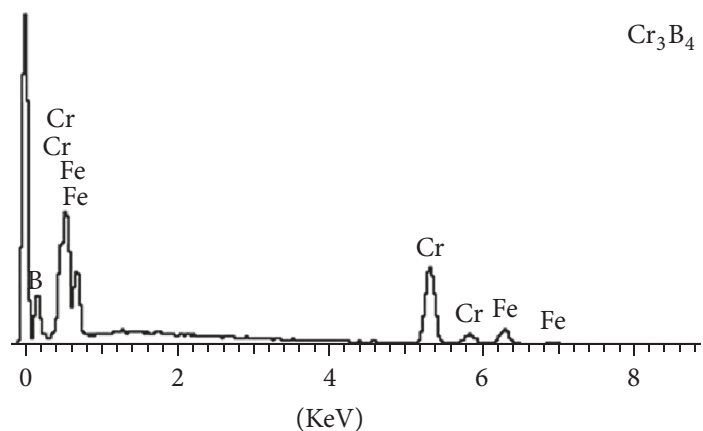

(c)

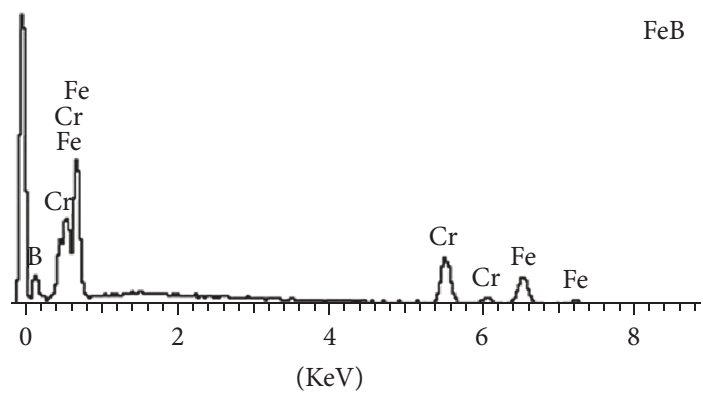

(e)

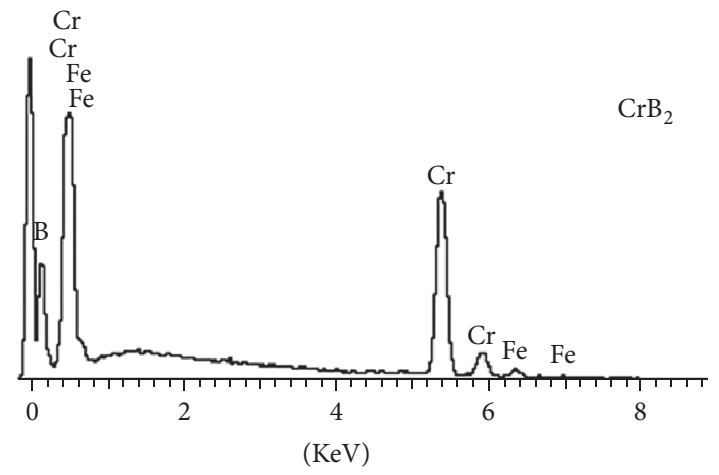

(b)

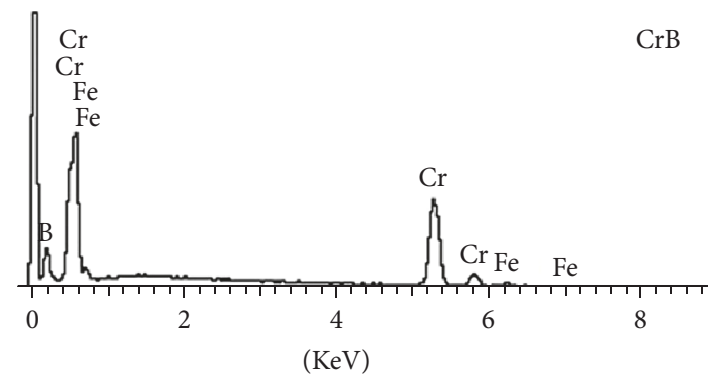

(d)

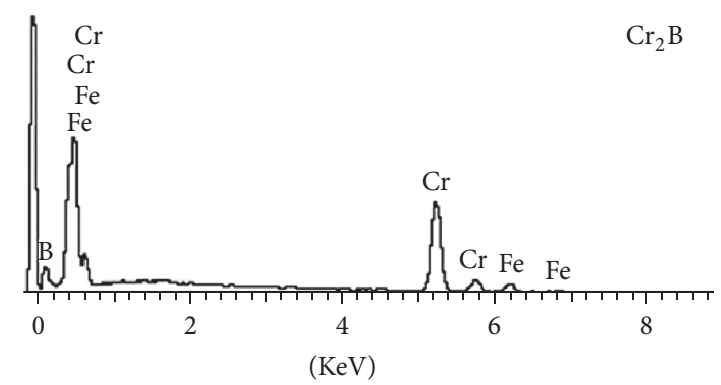

(f)

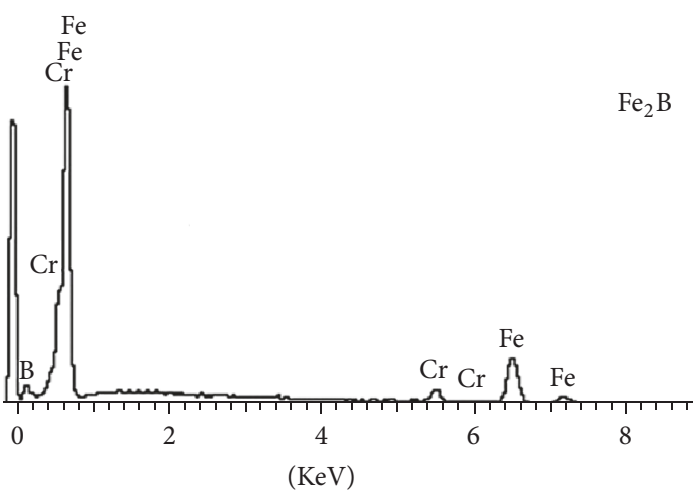

(g)

Figure 2: EDX spectrum of the $\mathrm{CrB}_{4}$ in $33 \mathrm{Fe}-62 \mathrm{~B}-5 \mathrm{Cr}$ alloy (a); $\mathrm{CrB}_{2}$ in $17 \mathrm{Fe}-65 \mathrm{~B}-18 \mathrm{Cr}$ alloy (b); $\mathrm{Cr}_{3} \mathrm{~B}_{4}$ in $8 \mathrm{Fe}-62 \mathrm{~B}-30 \mathrm{Cr}$ alloy (c); CrB boride in $15 \mathrm{Fe}-40 \mathrm{~B}-45 \mathrm{Cr}$ alloy (d); $\mathrm{FeB}$ boride in $50 \mathrm{Fe}-40 \mathrm{~B}-10 \mathrm{Cr}$ alloy (e); $\mathrm{Cr}_{2} \mathrm{~B}$ boride in $15 \mathrm{Fe}-40 \mathrm{~B}-45 \mathrm{Cr}$ alloy (f); $\mathrm{Fe}_{2} \mathrm{~B}$ boride in $50 \mathrm{Fe}-40 \mathrm{~B}-10 \mathrm{Cr}$ alloy (g). 


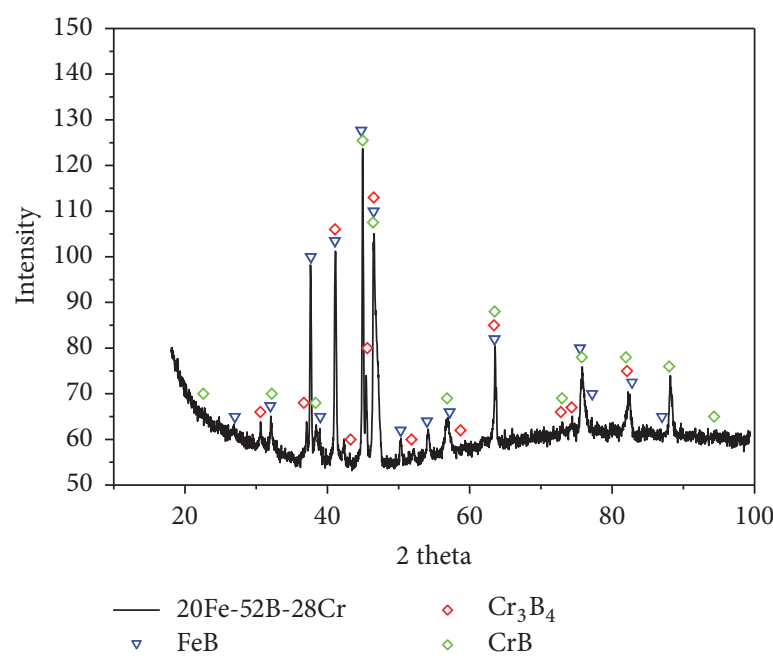

(a)

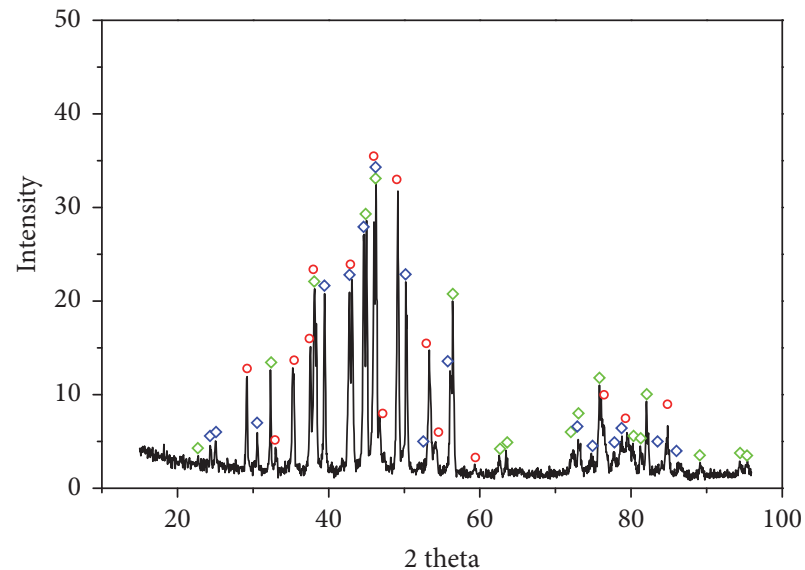

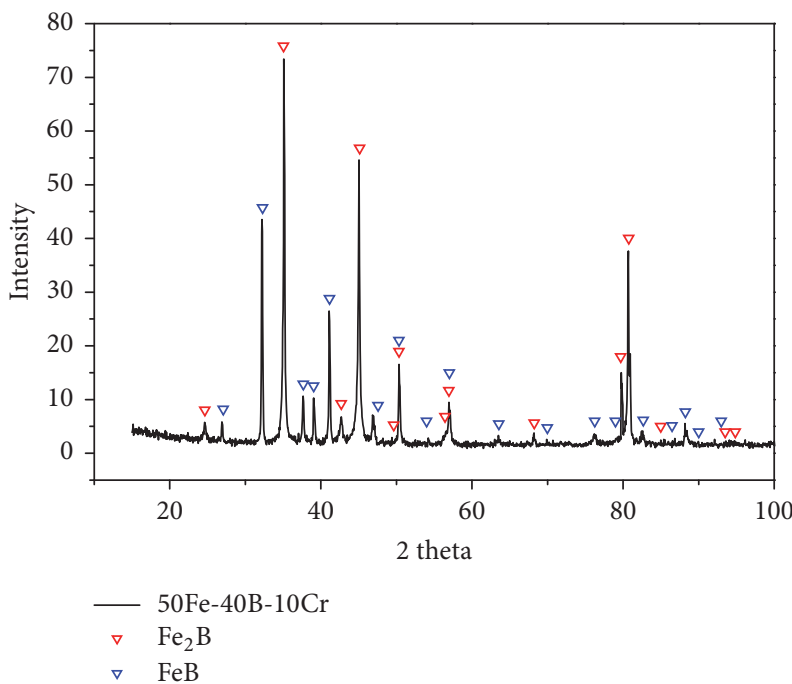

(b)

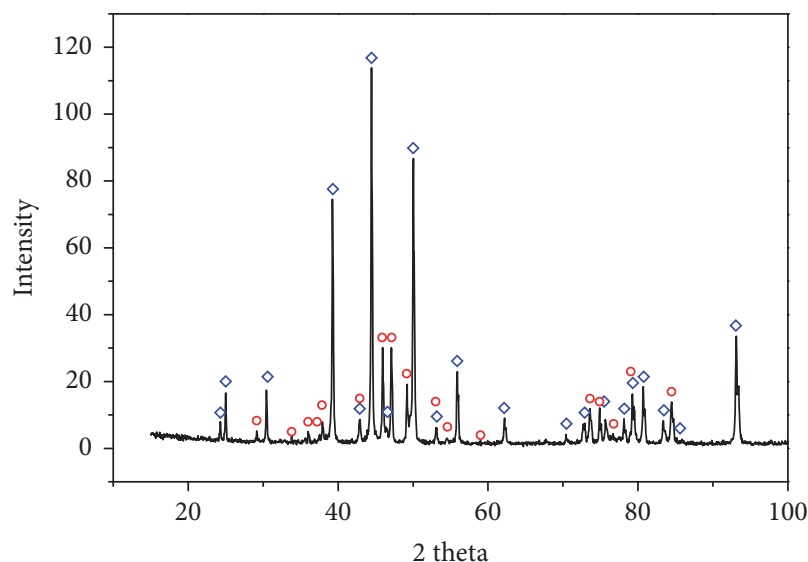

- 3Fe-35B-62Cr

$\diamond \mathrm{Cr}_{2} \mathrm{~B}$

- $\mathrm{Cr}_{5} \mathrm{~B}_{3}$

(d)

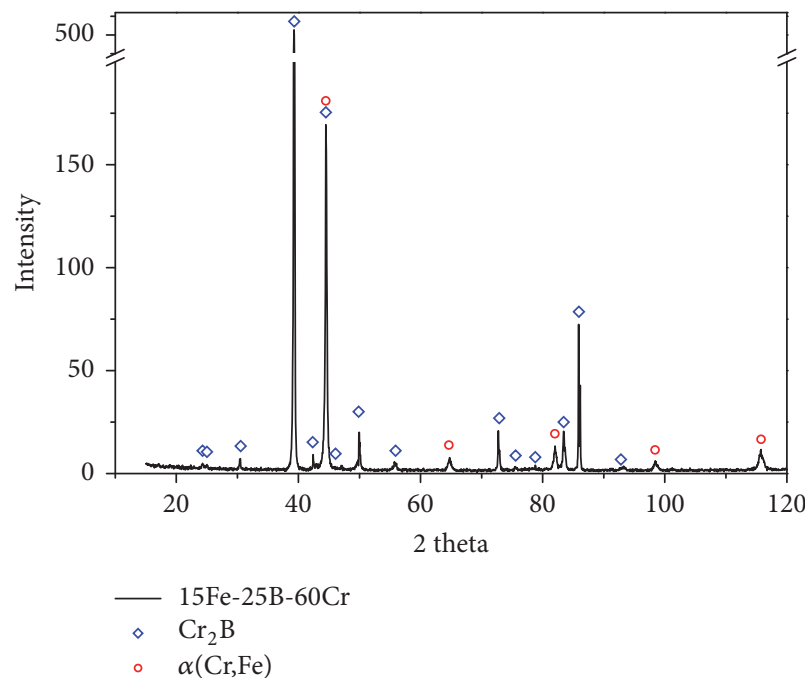

(e)

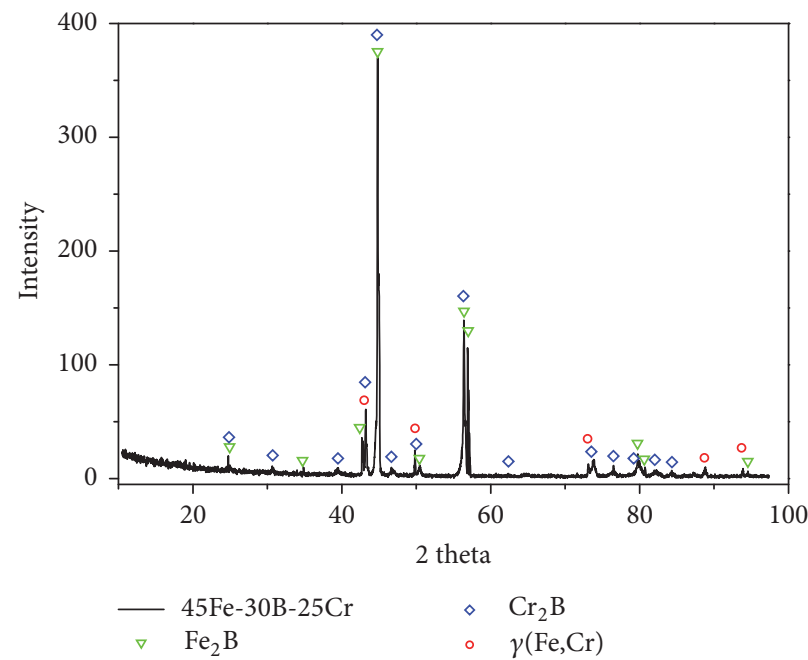

(f)

FIgURE 3: X-ray spectrum of the investigated B-Cr-Fe alloys after annealing at $1353 \mathrm{~K}$ : 20Fe-52B-28Cr alloy (a); $50 \mathrm{Fe}-40 \mathrm{~B}-10 \mathrm{Cr}$ alloy (b); $10 \mathrm{Fe}-38 \mathrm{~B}-52 \mathrm{Cr}$ alloy (c); 3Fe-35B-62Cr alloy (d); 15Fe-25B-60Cr alloy (e); 45Fe-30B-25Cr alloy (f). 


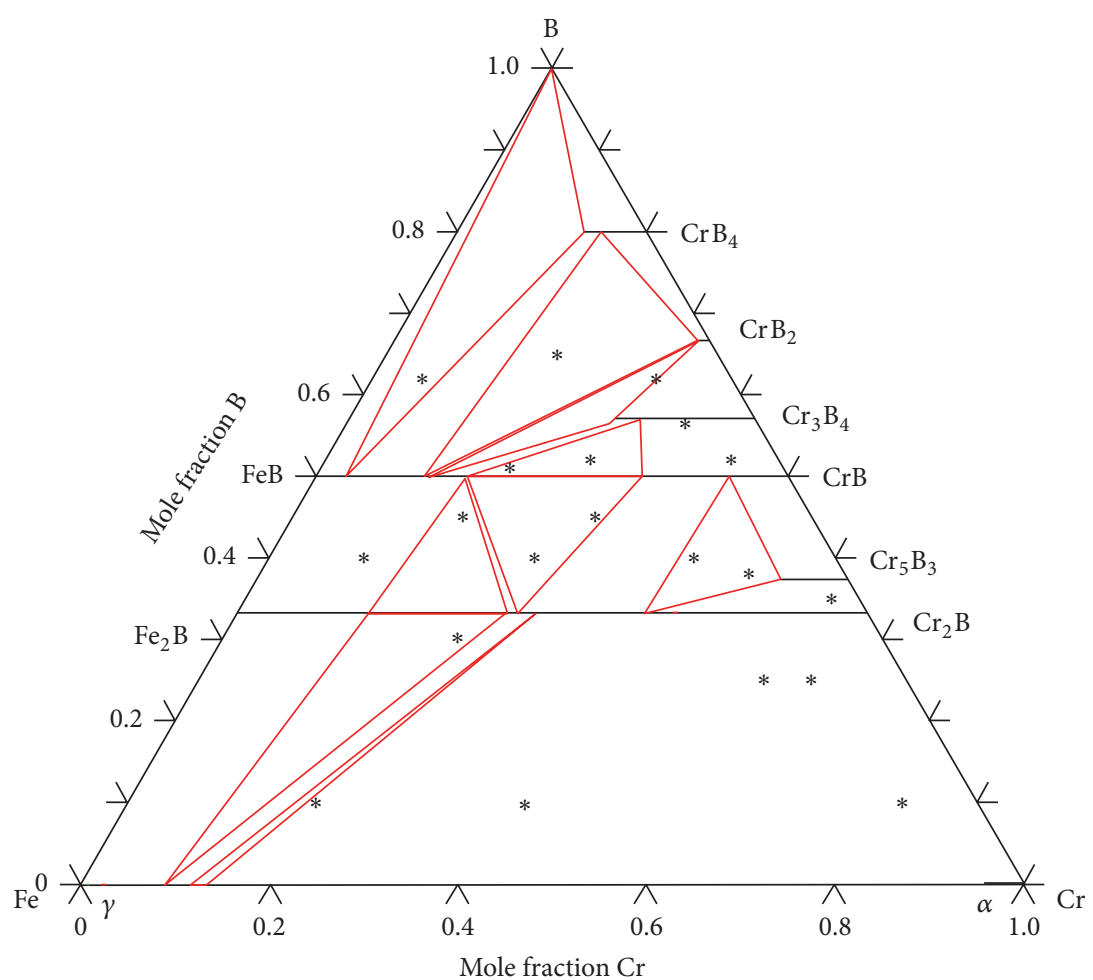

FIgURE 4: The experimentally determined isothermal section of the B-Cr-Fe phase diagram at $1353 \mathrm{~K}$. Compositions of model alloys are marked by $*$.

\section{Conclusions}

In the work, phase equilibria of the B-Cr-Fe model alloys at $1353 \mathrm{~K}$ were studied experimentally. The achieved results can be summarized as follows:

(i) Two iron borides $\mathrm{FeB}$ and $\mathrm{Fe}_{2} \mathrm{~B}$, six chromium borides $\mathrm{Cr}_{2} \mathrm{~B}, \mathrm{Cr}_{5} \mathrm{~B}_{3}, \mathrm{CrB}, \mathrm{Cr}_{3} \mathrm{~B}_{4}, \mathrm{CrB}_{2}$, and $\mathrm{CrB}_{4}$, and also iron and chromium solid solutions $(\alpha(\mathrm{Fe}, \mathrm{Cr})$, $\alpha(\mathrm{Cr}, \mathrm{Fe}), \gamma(\mathrm{Fe}, \mathrm{Cr}))$ and $\beta$-rhombohedral $\mathrm{B}$ are equilibrium phases in the system at $1353 \mathrm{~K}$.

(ii) 8 three-phase equilibria were found in the phase diagram at the temperature.

(iii) Solubilities of the third element in all binary borides were determined. High solubilities were found in $\mathrm{Cr}_{2} \mathrm{~B}, \mathrm{CrB}, \mathrm{Cr}_{3} \mathrm{~B}_{4}, \mathrm{FeB}$, and $\mathrm{Fe}_{2} \mathrm{~B}$ phases.

(iv) No ternary phase was found.

Based on the experimental results, isothermal section of the $\mathrm{B}-\mathrm{Cr}-\mathrm{Fe}$ system at $1353 \mathrm{~K}$ was established.

\section{Conflicts of Interest}

The authors declare that there are no conflicts of interest regarding the publication of this paper.

\section{Acknowledgments}

The present work was supported by Slovak Grant Agency (VEGA) under Grant no. 2/0153/15. Thanks are also due to Dr. P. Repovský for help at production of alloys.

\section{References}

[1] M. Klimenkov, E. Materna-Morris, and A. Möslang, "Boron effect on the microstructure of 9\% Cr ferritic-martensitic steels," Journal of Nuclear Materials, vol. 462, pp. 280-288, 2015.

[2] H. M. Heo, E. H. Jeong, S. H. Kim, and J. R. Kim, “Comparison between effect of $\mathrm{b}$ and $\mathrm{n}$ on the microstructure of modified 9Cr-2W steel during aging and creep," Materials Science and Engineering A-Structural Materials Properties Microstructure and Processing, vol. 670, pp. 106-111, 2016.

[3] L. Falat, V. Homolová, L. Čiripová, P. Ševc, and M. Svoboda, "Ageing effects on microstructure, mechanical properties, and fracture behaviour of $9 \mathrm{Cr}-1.5 \mathrm{Mo}-1 \mathrm{Co}-\mathrm{VNbBN}$ martensitic steel welded joint for high temperature application," Advances in Materials Science and Engineering, vol. 2017, Article ID 6824385, 14 pages, 2017.

[4] S. Q. Ma, J. D. Xing, H. G. Fu et al., "Interfacial morphology and corrosion resistance of $\mathrm{Fe}-\mathrm{B}$ cast steel containing chromium and nickel in liquid zinc," Corrosion Science, vol. 53, p. 2826, 2011.

[5] A. N. M. Idriss, S. Mridha, and T. N. Baker, "Laser and gtaw torch processing of Fe-Cr-B coatings on steel," Materials Science and Technology (United Kingdom), vol. 31, no. 3, pp. 355-360, 2015.

[6] J. Ptačinová, M. Drienovský, M. Palcut, R. Čička, M. Kusý, and M. Hudáková, "Oxidation stability of boride coatings," Kovove Materialy, vol. 53, no. 3, pp. 175-186, 2015.

[7] M. Zhong, C. Huang, and C. Tian, "The structural stabilities, mechanical properties and hardness of chromium tetraboride: compared with low-B borides," International Journal of Modern Physics B, vol. 30, no. 30, Article ID 1650201, 2016. 
[8] S. Wang, X. Yu, J. Zhang et al., "Crystal structures, elastic properties, and hardness of high-pressure synthesized $\mathrm{CrB}_{2}$ and $\mathrm{CrB}_{4}$," Journal of Superhard Materials, vol. 36, no. 4, pp. 279287, 2014.

[9] E. Gorbunov and F. M. Bodurjan, "Phase equilibria in ternary Cr-B-Fe system," Metalurgija Tverdych Splavov, vol. 16, pp. 172178, 1976 (Russian).

[10] M. B. Chepiga and J. B. Kuzma, "Fazovyje ravnovesia v sisteme Cr-Fe-B," Izvestija Vyssich Ucebnych Zavedenij, Chernaja Metalurgija, vol. 3, pp. 127-130, 1970.

[11] P. Rogl, "Cr-B-C (Chromium-Boron-Carbon)," in Phase Diagrams of ternary Metal-Boron-Carbon Systems, G. Effenberg, Ed., pp. 36-52, ASM international, 1998.

[12] E. Campbell and U. R. Kattner, "Assessment of the Cr-B system and extrapolation to the Ni-Al-Cr-B quaternary system," Calphad, vol. 26, pp. 477-490, 2002.

[13] D. Kotzott, M. Ade, and H. Hillebrecht, "Synthesis and crystal structures of $\alpha$ - and $\beta$ - modifications of $\mathrm{Cr}_{2} \mathrm{IrB}_{2}$ containing 4membered $\mathrm{B}_{4}$ chain fragments, the $\tau$-boride $\mathrm{Cr}_{7.9} \operatorname{Ir}_{14.1} \mathrm{~B}_{6}$ and orthorhombic $\mathrm{Cr}_{2} \mathrm{~B}$," Solid State Sciences, vol. 10, no. 3, pp. 291302, 2008.

[14] C. Gianoglio, G. Pradelli, and M. Vallino, "Solid state equilibria in the Cr-Fe-B system at the temperature of 1373K," Metallurgical Science and Technology, vol. 1-2, pp. 51-57, 1983.

[15] P. Villars, Pearson's Handbook, The Materials Information Society, Materials Park Ohio, USA, 1997. 

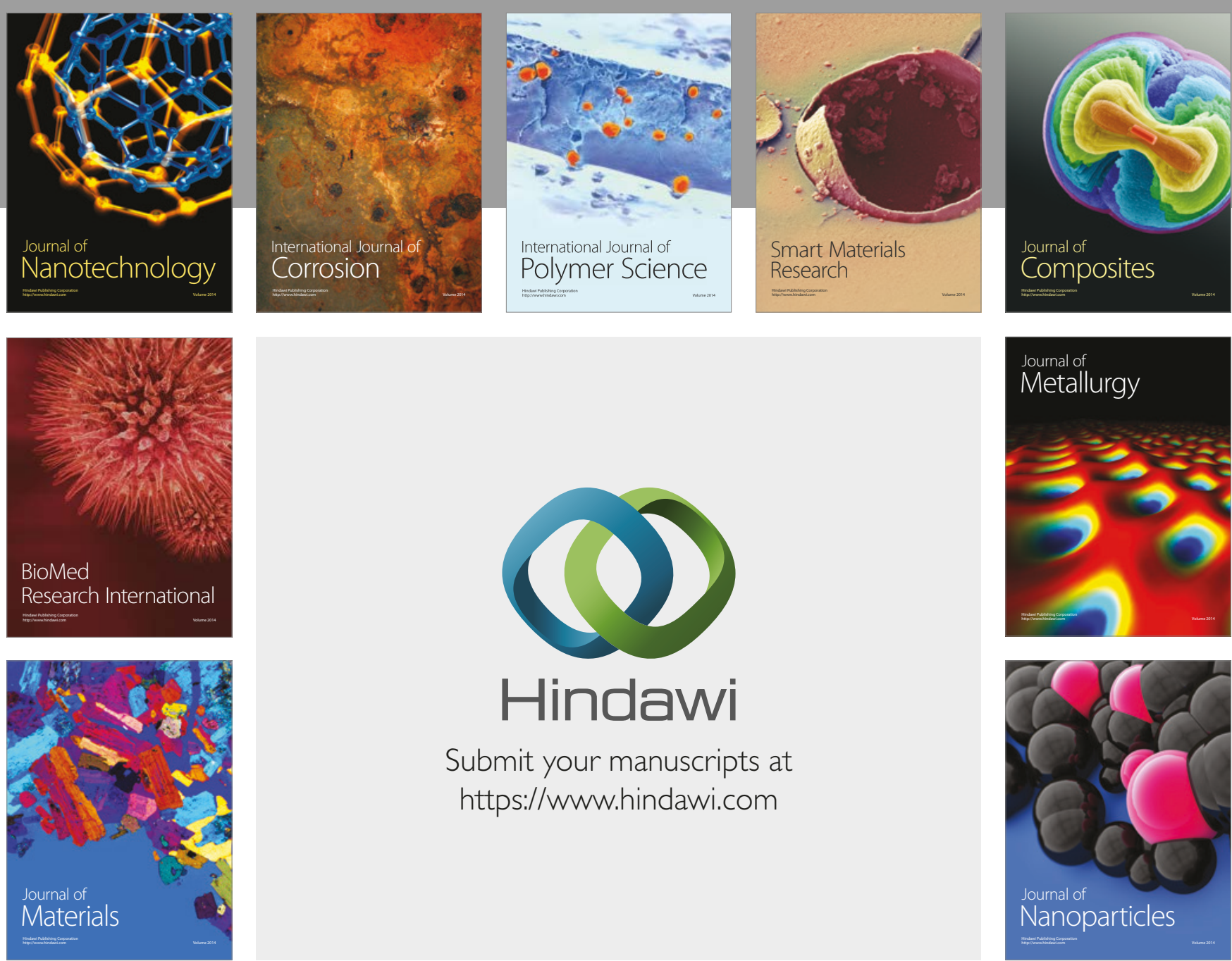

\section{Hindawi}

Submit your manuscripts at

https://www.hindawi.com
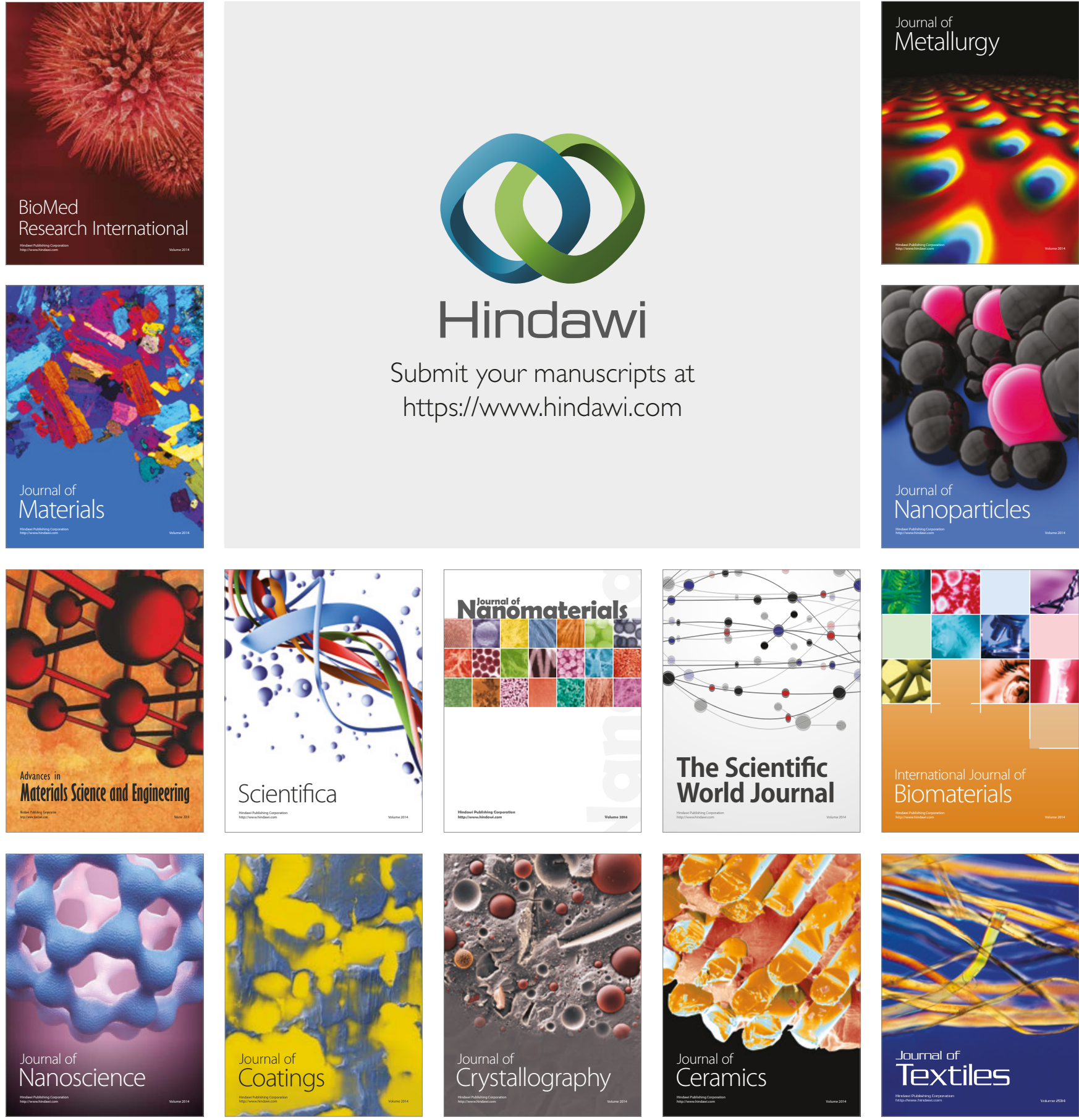

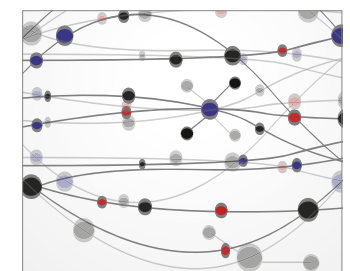

The Scientific World Journal
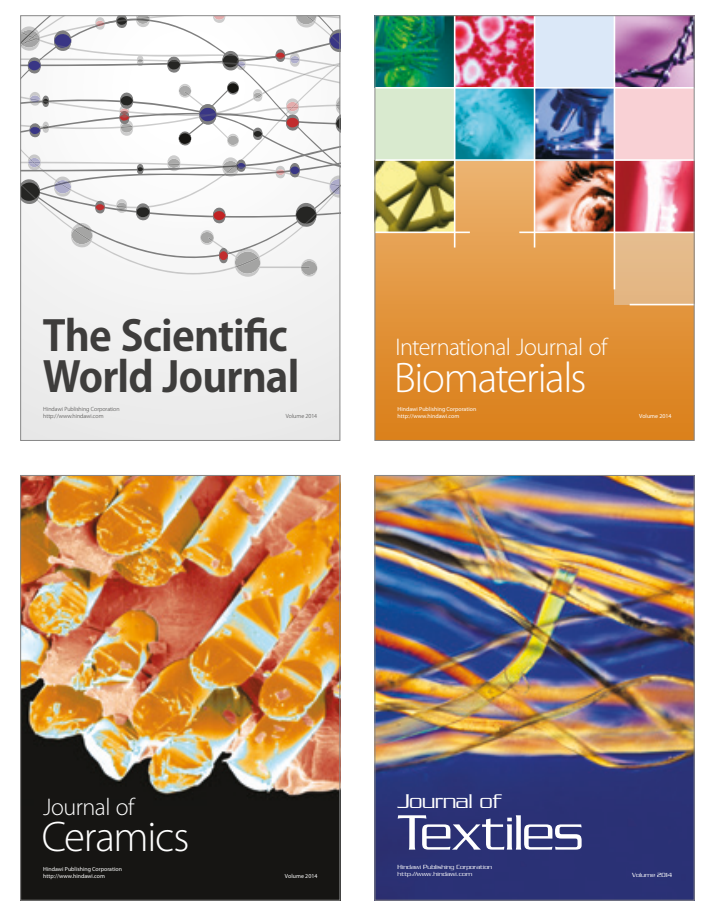